\title{
How It Feels to Be a Problem: Du Bois, Fanon, and the "Impossible Life" of the Black Intellectual
}

\author{
Ross Posnock
}

A growing chorus of thinkers is in effect writing postmodernism's obituary, inspired by a renewed sense of convergence and commonality among the world's regimes in the wake of recent transitions from communism to emerging market capitalism. One symptom of postmodernism's demise is the reemergence of the cosmopolitan and the universal, ideas stigmatized by the bias of the postmodern toward the particular and local. Indeed, according to the social theorist Jeffrey Alexander, a pluralistic universalism has now become the positive half of a binary whose other (polluted) term is nationalism, a dualism poised to replace the postmodern/modern as the defining binary code of the present. ${ }^{1}$ Edward Said, Martha Nussbaum, Tzvetan Todorov, Alain Finkielkraut, Kwame Anthony Appiah, and Julia Kristeva are among the thinkers who have engaged the possibilities and the limits of the postmodern and rejected its politics of identity and difference. ${ }^{2}$ Instead, they have (to borrow Kristeva's words),

An earlier version of this paper was read at "Making Americans, Making New Literatures," a conference at the Huntington Library, September, 1995. My thanks to Martha Banta for inviting me and to Charles Altieri, Vincent Pecora, Brook Thomas, and Kenneth Warren for their responses. I am grateful, too, for the comments of Karen Shabetai, Priscilla Wald, and Mary Esteve regarding later drafts.

1. See Jeffrey C. Alexander, Fin de Siècle Social Theory: Relativism, Reduction, and the Problem of Reason (New York, 1995), chap. 1. Others describe the shift to universalism as the rise of a post- or transnationalist globalism. See Frederick Buell, National Culture and the New Global System (Baltimore, 1994).

2. See Edward W. Said, Culture and Imperialism (New York, 1993); Martha Nussbaum, "Patriotism and Cosmopolitanism," Boston Review 19 (Oct.-Nov. 1994): 3-6; Tzvetan To- 
"chosen cosmopolitanism." This means, explains Kristeva, that "I have, against origins and starting from them, chosen a transnational or international position situated at the crossing of boundaries." Kristeva equates this ability to choose with democratic freedom, with the capacity to transcend the origins that have assigned to us biological and historical identity papers. ${ }^{3}$

Skepticism of postmodern tribalism's romance of identity offers a propitious moment for recovering the figure of the intellectual in its historical specificity, that is, the idea (and the offense) that gave birth to the term. "Les intellectuels" was first heard in 1898 to impugn those, like Zola, who dared speak for universal rather than French values during the hysterical chauvinism unleashed by the Dreyfus trial. To recover the intellectual is to recover a cosmopolitan universalism, and they both return not in defiance of but chastened by postmodern particularism, which favored the "organic" (Gramsci) and "specific" (Foucault) intellectual.

The contemporary turn sketched above is particularly salutary for the study of African American intellectual history, especially the history of black intellectuals. For here identity politics has long dominated, particularly in the form of a fetish of racial authenticity, of roots. This essay argues that such domination (practiced by whites and blacks alike) has made it difficult to discern that the black creative intellectual at the turn of the century emerged as a social type by resisting the lure of the prevailing ideology of the authentic. The foremost proponent of authenticity

dorov, On Human Diversity: Nationalism, Racism, and Exoticism in French Thought, trans. Catherine Porter (Cambridge, Mass., 1993); Alain Finkielkraut, The Defeat of the Mind, trans. Judith Friedlander (New York, 1995); Kwame Anthony Appiah, In My Father's House: Africa in the Philosophy of Culture (New York, 1992); and Julia Kristeva, Nations without Nationalism, trans. Leon Roudiez (New York, 1993).

3. Kristeva, Nations without Nationalism, p. 16. Analogously, David Hollinger urges a cosmopolitan multiculturalism that prefers "choice over prescription" (David A. Hollinger, Postethnic America: Beyond Multiculturalism [New York, 1995], p. 13). And Tobin Siebers defines the "principal task" of "cosmopolitan morality" as promoting "the act of choice" (Tobin Siebers, "The Ethics of Anti-Ethnocentrism," Michigan Quarterly Review 32 [Winter 1993]: 69). Long stigmatized by the left as privileged and apolitical, cosmopolitanism (like universalism) is a perennially contested concept. Bruce Robbins discusses the newly rehabilitated status of both ideas in his "Comparative Cosmopolitanisms," Secular Vocations: Intellectuals, Professionalism, Culture (New York, 1993), pp. 180-211.

Ross Posnock is Hilen Professor of American Literature at the University of Washington and author, most recently, of The Trial of Curiosity: Henry James, William James, and the Challenge of Modernity (1991). He is currently completing a book on black intellectuals and the politics of pragmatism, for which he was awarded a Guggenheim Fellowship in 1993. 
was Booker T. Washington, whose mostly white-funded Tuskegee machine normalized blackness as contented submission to a utilitarian life of agrarian labor. Washington's best-known antagonist, W. E. B. Du Bois, the crucial theorist and embodiment of the black intellectual, helped construct this new social type by insisting on the implicitly Dreyfusardian notion of the intellectual as bearer of the universal or, in Du Bois's terms, as "co-worker in the kingdom of culture." ${ }^{4} \mathrm{He}$ conceives this as a deracialized realm “above the Veil." But Du Bois's theorizing of the black intellectual was and is usually ignored or overshadowed by his simultaneous and overlapping work of creating what he called a "talented tenth" of "race men." ${ }^{5}$ Thus to link the universal and the black intellectual sounds discordant, as strange as asserting that the souls of black folk are uncolored or that $\mathrm{Du}$ Bois understands black intellectual as an oxymoron.

The arguments for each of these assertions organize this essay into two parts. The first constructs historical and thematic contexts, including a reading of Du Bois's famous collision with Washington as an instance of a larger historical pattern in the late nineteenth century in both the West and in West Africa, a pattern that reveals the social role of the intellectual as founded on a refusal of the ideology of the authentic. This refusal has rarely, if ever, been articulated more strenuously than in the life and work of Frantz Fanon. "Against origins and starting from them," Fanon and Du Bois fashion a performative cosmopolitanism that anticipates the contemporary moment of postidentity. ${ }^{6}$ The extremity of Fanon's turn from Negritude to universalism sets in relief Du Bois's own efforts to negotiate the racial particular and the unraced universal. In moving beyond authenticity, they both displace the originary Cartesian subject by deriving identity from action. In Fanon, this shift is analogous to his plea that anticolonial nationalism move rapidly from national consciousness (pre-

4. W. E. B. Du Bois, The Souls of Black Folk, in Writings, ed. Nathan Huggins (New York, 1986), p. 365; hereafter abbreviated $S$. "I followed the Dreyfus case," notes Du Bois, and remarks that the year (1894) he traveled in France was the year Dreyfus was arrested and tried for treason (Du Bois, The Autobiography of W. E. B. Du Bois: A Soliloquy on Viewing My Life from the Last Decade of Its First Century [New York, 1968], p. 122; hereafter abbreviated $A$ ). Du Bois was in Paris again in 1900 when the scandal was raging anew, for the year before Dreyfus had been convicted a second time.

5. The talented tenth, as Du Bois conceived it, was responsible for guiding the American Negro "to its highest cultural possibilities" ( $A$, p. 236). Shamoon Zamir, Dark Voices: W. E. B. Du Bois and American Thought, 1888-1903 (Chicago, 1995), astutely emphasizes Du Bois's penchant for simultaneously adopting conflicting roles and perspectives; see pp. 98, 109. But, according to Zamir, Du Bois conceives the aim of the talented tenth as uplifting black folk "into an acceptance of cultural values that are more or less identical to those of the white aristocracy" (p. 151). This suggests that Du Bois's aim is to have high culture whiten blacks, when actually, as we shall see, Du Bois seeks to deracialize culture.

6. The pairing of Du Bois and Fanon is not uncommon, but the way I am pursuing it here is. For recent instances, see Thomas Holt, "Marking: Race, Race-Making, and the Writing of History," American Historical Review 100 (Feb. 1995): 1-20, and Zamir, Dark Voices, pp. 207-10. 
occupied with who people are) to political and social consciousness (focused on people acting in relation to others). ${ }^{7}$ The contexts developed in part one situate the subject of part two-how a figure who had been deemed a freak of nature requiring containment (at least since the attestation affixed to Phillis Wheatley's book of poems in 1773) managed to emerge as a social category. The emergence of black literary intellectuals depended on their devising an aesthetic of deferral, vagueness, and open margin, modes of literary representation that simultaneously became political strategies of denaturalization in a society where racist stereotypes reigned serenely as "nature."

\section{1. "Above the Veil ... Walked Souls Alone, Uncolored"}

That the souls of black folk are uncolored seems flatly contradicted by the fact that Du Bois is the father of the black soul movement. But The Souls of Black Folk (1903) gives a more complicated answer. It is double, like everything in Du Bois's work. Contained by Jim Crow America's color line, within the "Veil of Race," black people are judged by their skins and not by their souls; their lives often grow "choked and deformed" ( $S$, p. 510). But "above the Veil," in the "kingdom of culture," souls walk "uncolored," enjoying "freedom for expansion and self-development" $(S$, pp. $511,509,437) .{ }^{8}$ Faith that this freedom will one day "rend the Veil" comprises the very "meaning" of the sorrow songs of the slaves. These ancestral voices, the greatest expression of American art, says Du Bois, herald "a truer world" where "men will judge men by their souls and not by their skins" ( $S$, pp. 545, 538, 544). In The Souls of Black Folk, then, Du Bois sets himself a double project: he works both within and beyond the Veil, celebrating the "Negro soul" in the former, while preparing black Americans for the "chance to soar" "above the Veil," where the "sovereign human soul" expands, protected by "the centres of culture" ( $S$, pp. 365, $438,437)$.

The fact that $\mathrm{Du}$ Bois tends to be confined to the familiar role of talented tenth race activist within the Veil attests to the presiding ideology of authenticity. It anchors identity to an immutable race or category as decisively as the one-drop rule of white supremacists and makes paramount the essentialist question of who and what counts as truly black.

7. Joan Cocks also makes this distinction. See Joan Cocks, "On Nationalism: Frantz Fanon, 1925-1961; Rosa Luxemburg, 1871-1919; and Hannah Arendt, 1906-1975," in Feminist Interpretations of Hannah Arendt, ed. Bonnie Honig (University Park, Pa., 1995), pp. 22145 , esp. p. 223.

8. "Uncolored" is how Du Bois describes the world his dead son enjoyed: "He knew no color-line, poor dear. . . In his little world walked souls alone, uncolored and unclothed. I-yea, all men-are larger and purer by the infinite breadth of that one little life" ( $S$, p. 509). 
Even Frederick Douglass's attempt at an answer is dictated by the question's constricting terms. Douglass remarked of Martin Delany, his onetime North Star colleague and rival, "[I] thank God for making me a man simply; but Delany always thanks him for making him a black man." ${ }^{9}$ That $\mathrm{Du}$ Bois positions himself outside the Delany and Douglass polarities is a measure of his suppleness. In a characteristic self-representation he boasts of his Negro, French, and Dutch blood, but "thank God! no 'AngloSaxon." ${ }^{10}$ By flaunting his own hybridity, his cosmopolitan multiplicity, he renders incoherent a need to be true to a prior essence-be it abstract humanism or unalloyed blackness. Neither "a man simply" nor only a black man, Du Bois exceeds categories.

Du Boisian hybridity is indifferent to white or black fantasies of purity; indeed, the famous start of The Souls of Black Folk stages what could be called a primal scene of inauthenticity. It reveals that the African American is "born with a veil" and "gifted with second-sight" in an American world that "yields him no true self-consciousness" ( $S$, p. 364). Du Bois seeks a "better and truer self" but does not desire to dissolve his "double self" into unitary identity. Rather, his concern is less identity than action; he wants to resolve the paralysis of black agency, of "turning hither and thither in hesitant and doubtful striving," by making it "possible for a man to be both a Negro and an American, without being cursed" ( $S$, p. 365). How to maintain this doubleness is the explicit question, one itself doubled by what Du Bois calls "ever an unasked question": How is it possible to be both black and a literary intellectual ( $S$, p. 363)? To devise an answer in 1900 would require carving out an interstitial space within a social order partitioned by color, where the dominant had "epidermalized Being." 11

But "my black skin is not the wrapping of specific values," Fanon would remark half a century later, challenging the equation produced by an ideology of authenticity. ${ }^{12}$ Fanon reveals how authenticity is wielded as a weapon of colonial control that propagates fantasies of regression, embodying them in stereotypes and nostalgia, twin devices of imperialism. They seal Fanon in a "crushing objecthood" that weighs him down with a triple burden of responsibility - for his body, race, and ancestors $(B S$, p. 109). When he examines his objecthood, he finds it comprises an internalized montage of stereotypes: "I discovered," says Fanon, "my blackness, my ethnic characteristics; and I was battered down by tomtoms, cannibalism, intellectual deficiency, fetichism, racial defects, slaveships" (BS, p. 112). Colonizers circulate such imagery of the authentic

9. Frederick Douglass, quoted in Vincent Harding, There Is a River: The Black Struggle for Freedom in America (New York, 1981), p. 149.

10. Du Bois, Darkwater: Voices from within the Veil (1920; New York, 1975), p. 9.

11. Charles Johnson, Oxherding Tale (New York, 1984), p. 52.

12. Frantz Fanon, Black Skin, White Masks, trans. Charles Lam Markmann (New York, 1967), p. 227; hereafter abbreviated $B S$. 
while encouraging "the traditions of the indigenous society," defending "the native style," ${ }^{13}$ and urging intellectuals to "go native" and busy themselves preserving an "arrested image" of primitive black artistic genius. This production of nostalgia helps distract intellectuals from joining with the colonized in the present, "that fluctuating movement" and "zone of occult instability" that houses the "seething pot out of which the learning of the future will emerge" (WE, pp. 227, 225). ${ }^{14}$

To live in the present demands a radical act of deracination. And Fanon's career compels because it actually met the demand. His life of willed exile and self-invention may be unprecedented; Albert Memmi has judged it "impossible" in its lavish indifference to origins or limits, be they of homeland or of "blood." ${ }^{15}$ Fanon's most famous books conclude with pleas for upheaval. Black Skin, White Masks urges a "leap" that would introduce "invention into existence" (BS, p. 229). And in The Wretched of the Earth his goal is nothing less than establishing a "fundamentally different set of relations between men," a "new humanity" that will come to define a "new humanism" and a "new man" (WE, pp. 246, 316). Despising the pseudo-universalism of European humanism, which functioned to disguise imperialism, Fanon embraced, in his words, "the universality inherent in the human condition" (BS, p. 10).

Admittedly, to stress the universalist commitments of Du Bois and Fanon may seem surprising, even perverse, in the face of substantial racial grounds of comparison. To traverse them quickly: declaring in The Souls of Black Folk that the Negro is "a sort of seventh son" with "a message for the world," Du Bois reaffirms the romantic racialism he had inherited from Hegel, Herder, and Alexander Crummell and becomes the father of the international black soul movement $(S$, pp. 364, 365). Celebrating the beauty of blackness and black African culture, he helped create PanAfrican solidarity as a defense against what he called the "logic of the modern colonial system" that fueled the global aims of European imperialism. ${ }^{16}$ In the thirties, The Souls of Black Folk served as a founding text of the black Francophone Negritude movement of Léopold Senghor and Aimé Césaire, the latter a teacher who greatly influenced Fanon, who, in turn, was the posthumous mentor of black power nationalists in America.

13. Fanon, The Wretched of the Earth, trans. Constance Farrington (New York, 1991), p. 242, and see pp. 220-21; hereafter abbreviated $W E$.

14. Nostalgia also has a positive moment for Fanon. Native intellectuals appropriate the colonial production of nostalgic tribalism to help emancipate them from the supremacy of white culture and eventually to achieve a "universal standpoint"” (WE, p. 218).

15. See Albert Memmi, "The Impossible Life of Frantz Fanon," Massachusetts Review 14 (Winter 1973): 9-39.

16. Du Bois, W. E. B. Du Bois: A Reader, ed. David Levering Lewis (New York, 1995), p. 677. The two most important discussions of Du Bois and the black soul movement are found in Joel Williamson, The Crucible of Race: Black/White Relations in the American South since Emancipation (New York, 1984), and Eric Sundquist, To Wake the Nations: Race in the Making of American Literature (Cambridge, Mass., 1993). 
But the contemporary turn from identity politics has made it easier to discern that neither man regarded nationalism or Negritude as an endpoint or a fixed identity; rather they were moments, critical stages, to be worked through to reach a telos of the universal. ${ }^{17}$ This perspective sponsors a raceless society without erasing the historical experience of racism that unites all black and colonized people. In other words, Du Bois and Fanon would decline Sartre's Hegelian invitation, in his seminal essay on Negritude, to look "to the end of particularism in order to find the dawn of the universal." ${ }^{18}$ Instead, they insist on a dialectic that preserves the interplay of the universal and the particular rather than liquidating them in an optimistic teleology. Fanon, for instance, speaks of a "two-fold emerging": "it is at the heart of national consciousness that international consciousness ... grows" (WE, pp. 248, 247-48)..$^{19}$

If nationalism and internationalism are dialectically entwined for $\mathrm{Du}$ Bois and Fanon, the relation between race man and intellectual is a more conflicted one. In Du Bois especially both roles jostle against each other, as we will see, and his effort at balancing them is a source of creative tension throughout his career. In his autobiography Dusk of Dawn, Du Bois candidly calls the self-effacing race leader a "prisoner" of his group, unselfish, loyal, and self-sacrificing. Yet these very virtues "congeal," making him "provincial" and embittered, isolated from the "environing race." ${ }^{20}$ Provincialism is Du Bois's persistent enemy and spurs his investment in the intellectual's universalist ambitions. At the start of Black Skin,

17. This view of Du Bois diverges from Appiah's influential judgment that he never escaped the romantic racialism that he disavowed because it underwrote his yearning for an African homeland. Yet, as Priscilla Wald argues, Appiah ignores Du Bois's strategic uncertainty about race throughout his career. Even at his most Afrocentric, as in "The Conservation of Races" (1897), Du Bois insists that "race identity" is provisional, to be upheld until "the ideal of human brotherhood has become a practical possibility" (Du Bois, "The Conservation of Races," Writings, p. 825). Wald rightly discerns an analogy between Du Bois's statement above and Fanon's construction of national consciousness as provisional, a prelude to a global vision. See Priscilla Wald, Constituting Americans: Cultural Anxiety and Narrative Form (Durham, N.C., 1995), pp. 209, 338.

18. Jean-Paul Sartre, "Black Orpheus," trans. John MacCombie, "What Is Literature?" and Other Essays (Cambridge, Mass., 1988), p. 329. In this essay Sartre reduces Negritude to a transitional term in a dialectic whose synthetic moment is a society without races or memory of racism. Fanon protests that "Sartre had forgotten that the Negro suffers in his body quite differently from the white man" (BS, p. 138). Sartre's reduction, in turn, elicited Fanon's famous pages in Black Skin, White Masks narrating his anguished ambivalence about Sartre's Hegelian dialectic. It should be added that Fanon's commitment to a dialectic of the universal and the particular is in tension with what would short-circuit it-his Nietzschean leap of invention.

19. Said's reading of Fanon in Culture and Imperialism is emblematic of the current turn from identity politics. Said's Fanon is anti-identitarian in his skepticism of nationalism and postnationalist in his suspicion of national consciousness as anything more than temporary, until the colonizer leaves.

20. Du Bois, Dusk of Dawn: An Essay toward an Autobiography of a Race Concept, in Writings, p. 651 ; hereafter abbreviated $D D$. 
White Masks, Fanon describes his project as "nothing short of the liberation of the man of color from himself," the exchange of racial for human identity ( $B S$, p. 8). For Fanon, the native intellectual turns toward the possibility of this freedom when he discovers that he "cannot go forward resolutely unless he first realizes the extent of his estrangement" from the people ( $W E$, p. 226). Thus he resists the plunge into authenticity encouraged by imperialists and grasps the paradox that achieving transparent oneness with the masses is not a basis for revolution but a "blind alley," ending in a "banal search for exoticism" ( $W E$, pp. 220, 221).

Fanon replaces authenticity with the imperative of making oneself a "new man" in the present. Invention is especially urgent because the colonized black intellectual embodies a contradiction in terms in a white society where the "Negro is fixated at the genital; or at any rate he has been fixated there" ( $B S$, p. 165). To whites the sight of a "black man who quotes Montesquieu" is anomalous and alarming; he "had better be watched" (BS, p. 35). Surveillance is required because the black intellectual seems a walking category mistake, one that eludes the control of stereotype. As colonialism's prime instrument of identity, stereotype serves to disavow the threat of difference by reactivating, as Homi Bhabha points out, the primal fantasy of fetishism - the subject's desire to restore "originality" and "pure origin" to an object and thereby arrest the play of difference. ${ }^{21}$ In this light, the black intellectual is a threatening oxymoron, immune to the stereotype's regressive fantasy of authenticity. Significantly, when Fanon does invoke the possibility of moving beyond the fetish of stereotypes to reach "authentic" exchange between white and black it is on the condition that both renounce authenticity's flight to origins and identity: "The Negro is not. Any more than the white man. Both must turn their backs on the inhuman voices which were those of their respective ancestors in order that authentic communication be possible" (BS, p. 231). Fanon inverts the trajectory of authenticity by defetishizing it and stripping it of foundations, thus (unwittingly) reanimating the crisis of origins that perennially attends the figure of the intellectual. To this motif we will briefly turn.

When the radical French nationalist Maurice Barrès hurled the imprecation déracinés at the intellectuals during the Dreyfus affair, his indictment was historically resonant. For the charge of deracination names the primal sin of the intellectuals. ${ }^{22}$ And not just Western intellectuals. The

21. Homi K. Bhabha, The Location of Culture (New York, 1994), p. 75.

22. Déraciné recalls, inadvertently, the rootless mobility of the first group of selfconsciously oppositional intellectuals, the Goliards. Emergent in the twelfth century, the Goliards were wanderers from various class affiliations who severed their ties with home and abandoned the monastic, rural cloisters to move from city to city following the master currently in fashion. Jacques Le Goff calls them a fledgling urban intelligentsia, "escapees" from the High Middle Ages's attempt to "put and keep everyone in his place, at his task, in 
people who have been called the first "literate intellectuals of early colonial Africa" were the famous "recaptives," or "liberated" Africans of Sierra Leone's Freetown on the coast of West Africa, those whom Basil Davidson has called a "unique community." Except in neighboring Liberia, "there was no other people like them." Rescued by British naval patrols raiding slave ships bound for the Americas (from 1807 to the 1860s), recaptives had been saved from a life of enslavement, yet "at the same time, they were now cut sharply adrift from their own homeland cultures. ... They had to build a new life for themselves." ${ }^{23}$ This included devising a new language called Creole, which also became their collective name. Upperclass Creoles became famous for the degree to which they modeled themselves on their saviors. Their literary culture was Anglophilic, and they lived "with as much Europeanized elegance as they could afford," favoring heavy British woolens, collars, and high hats even though they were unsuited to the climate. ${ }^{24}$ Their weddings were particularly grand and ostentatious displays, and a cult of dandyism flourished in Freetown. Such behavior outraged African cultural nationalists like Edward Wilmot Blyden, who worked with Crummell in Liberia and lived in Sierra Leone in the early 1870s. Although himself "the most westernized of West Africans," in the words of his biographer, Blyden's objects of special animus were the "Europeanized African[s]" who populated Freetown. He sought to Africanize the recaptives, including a failed attempt at a Dress Reform Society. Condemning Creoles as "unnatural and artificial," he called them "apes" and parasites. ${ }^{25}$ Blyden's friend Booker T. Washington would have heartily concurred.

In 1903 Washington assailed those who disrupted a speech of his in

his order, in his particular condition" (Jacques Le Goff, Intellectuals in the Middle Ages, trans. Teresa Lavender Fagan [Cambridge, Mass., 1993], p. 26).

23. Basil Davidson, The Black Man's Burden: Africa and the Curse of the Nation-State (New York, 1992), pp. 26, 25.

24. Christopher Fyfe, Africanus Horton, 1835-1883: West African Scientist and Patriot (New York, 1972), p. 40. It is tempting to regard Creole culture as a particularly egregious instance of imperialist-mandated assimilation, a betrayal of a people's Africanness. But as Fyfe, a historian of Sierra Leone, reminds us, the Sierra Leone situation runs counter to usual colonialist patterns. For one thing, the Creoles were not a conquered but a rescued people. Hence the British "did not appear to them as a machine of colonial repression. They did not feel themselves in a "colonial situation"" of racist paternalism (p. 10). Instead, they identified with the British and felt loyalty (see p. 11). What else should they have felt? asks Davidson. They were enthusiastic about "imperial Britain and its navy" because "without this power they or their fathers or mothers would have died in the infamous and stinking decks of slave ships" (Davidson, The Black Man's Burden, p. 29).

25. Hollis R. Lynch, Edward Wilmot Blyden: Pan-Negro Patriot, 1832-1912 (London, 1967), p. 242; Edward Wilmot Blyden, Black Spokesman: Selected Published Writings of Edward Wilmot Blyden, ed. Lynch (London, 1971), p. 224; Blyden, quoted in Leo Spitzer, The Creoles of Sierra Leone: Responses to Colonialism, 1870-1945 (Madison, Wisc., 1974), p. 113. 
Boston as "artificial" men, "graduates of New England colleges." ${ }^{26}$ And in his 1911 recounting of the incident, which had become known as the Boston riot, Washington gave a name to his unnatural enemies-"people who call themselves "The Intellectuals." They live "at a distance," in a world of "theories, but they do not understand" people and things. ${ }^{27}$ In regarding the intellectual as contra naturam, Washington in effect reclaimed the French nationalist sense of the word. And he also wrested the term away from William James, who in 1907 had become the first to enter intellectual into popular American discourse. James used it as an honorific standing "for ideal interests solely": “Les intellectuels”! What prouder club-name could there be than this one, used ironically by the party . . . of every stupid prejudice and passion, during the anti-Dreyfus craze, to satirize the men in France who still retained some critical sense and judgment!" 28

Nearly a decade before his call for a "class consciousness" of the college educated, James had been anticipated by his former Harvard student Du Bois. Distrusted by his arch rival Washington as one of the "artificial" men of the New England colleges, Du Bois shared what James would call the need to maintain the "critical sense, the sense for ideal values" in a democracy that is permanently "on its trial," always capable of a "self-poisoning" that would enthrone mediocrity and greed ("SV," pp. 1244,1245$)$. In his 1898 Fisk University commencement address Du Bois praised colleges for providing "a glimpse of the higher life, the broader possibilities of humanity." ${ }^{29} \mathrm{He}$ warned that a democracy without the college bred would lack "yeast," ${ }^{30}$ an image James repeats in calling the college bred "the yeast-cake for democracy's dough" ("SV," p. 1247). Like any race, "the Negro race . . . is going to be saved by its exceptional men," declares Du Bois in 1903, and he calls for a black "aristocracy of talent and character" (“TT," pp. 842, 847). This talented tenth emerged as a critical mass of trained professionals and business men, including creative intellectuals - "leaders of thought and missionaries of culture"as well as doctors, lawyers, merchants, realtors, farmers, and, above all, "teachers, and ... teachers of teachers." All of them together embody "the promise of black men" that will inspire those in the masses "worth the saving” (“TT," pp. 861, 852, 847).

In depicting a black aristocracy, Du Bois avoids racial essentialism by

26. Quoted in Lewis, W. E. B. Du Bois: Biography of a Race, 1868-1919 (New York, 1993), p. 301.

27. Booker T. Washington, My Larger Education: Being Chapters from My Experience (Garden City, N.Y., 1911), pp. 120, 113, 120.

28. William James, "The Social Value of the College-Bred," Writings, 1902-1910, ed. Bruce Kuklick (New York, 1987), p. 1246; hereafter abbreviated "SV."

29. Du Bois, "Careers Open to College-Bred Negroes," Writings, p. 827; hereafter abbreviated "C."

30. Du Bois, "The Talented Tenth," Writings, p. 847; hereafter abbreviated "T T." 
instead creating a dialectic of the universal and the particular. He enunciates "three universal laws"-of work, sacrifice, and service-that "in each age" differ in application (“C," pp. 829, 830). You will misunderstand the age and risk despair, Du Bois warns the Fisk graduates, if these universals are left abstract, not threaded with racial particularity. Only a double perspective balances the fact that late nineteenth-century modernity is unprecedented in its "human opportunity" and "in the broadness of its conception of humanity" with another fact: that as "American Negroes" "upon the threshold of the twentieth century" his listeners live in a "strange environment and unusual conditions"- the medieval caste system called Jim Crow (“C,” pp. 831, 830). A productive life will depend on negotiating the universal through the particular and vice versa. Du Bois concludes by reminding Fisk graduates to cherish their membership in a "dark, historic race" and in "that vast kingdom of culture that has lighted the world from its infancy and guided it through bigotry and falsehood and sin" ("C," p. 840). To live in the ideal of "service" makes attainment of the "broadest, deepest self-realization" simultaneously the way to make life "broad and full and free for all men and all time" ("C," p. 832).

$\mathrm{Du}$ Bois's dialectic, in short, does not make culture a code word for Anglo-Saxonism. This equation is made, understandably, by the recaptives of Sierra Leone and, ironically, by their would-be redeemers, Blyden and Crummell. And it is made also by William Ferris, the Yaleand Harvard-educated, fiercely anti-Bookerite, itinerant black intellectual whose nearly thousand-page work The African Abroad (1913) takes as its frontispiece a photograph of a splendid reception at the governor's manse in Freetown. Ferris's book articulates what the photograph announces-his sense of affinity with the refined Anglophilia of Sierra Leone's Creole upper class. Despising the term Negro, Ferris pleads for "Negrosaxon" as a replacement. ${ }^{31}$ His neologism is meant to stress the mixed blood of a majority of American blacks, their lack of "ethnological integrity" and nationalist spirit $(A A, 1: 296)$. But the word most clearly suggests Ferris's Anglophilia, which ultimately vitiates his obsessively repeated point (and plea) that the Negro is a "full-fledged man" and demands to be treated as a human being $(A A, 1: 329)$. It turns out that for Ferris human being has not a universal reference but a racial one-AngloSaxon-and the Negrosaxon "must become a black white man." Then "he can hope to be made over into the image of God" ( $A A, 1: 304)$. One reason $\mathrm{Du}$ Bois does not equate humanity and whiteness is that he considers America's "religion of whiteness" 32 to be little more than a desperate disavowal of the fact that the country is miscegenated, born of a

31. William H. Ferris, The African Abroad, or, His Evolution in Western Civilization, Tracing His Development under Caucasian Milieu, 2 vols. (1913; New York, 1968) 1:297; hereafter abbreviated $A A$.

32. Du Bois, "The Souls of White Folk," Writings, p. 924. 
"blood-brotherhood" between black and white ( $S$, p. 545). This leads him at the end of The Souls of Black Folk to scoff at Protestant America's pride of possession: "Your country? How came it yours? Before the Pilgrims landed we were here" $(S$, p. 545). With "mingled ... blood" his premise (S, p. 545), Du Bois erects the "ideal of human brotherhood" as his telos. ${ }^{33}$

Ferris's solution-becoming a "black white man"-is Fanon's dilemma. Given that the colonized becomes whiter "in proportion to his adoption of the mother country's cultural standards," whitening is inscribed as the very condition of becoming a black intellectual $(B S$, p. 18; see p. 192). Fanon speaks of Martinicans who steep "themselves in Montesquieu or Claudel for the sole purpose of being able to quote them" because "they expect their color to be forgotten" through "their knowledge of these writers" ( $B S$, p. 193). The effort succeeds on the condition that the Negro be "forever in combat with his own image" (BS, p. 194). This is the price exacted by a society whose "collective unconscious" (Fanon borrows and alters Jung's term) produces an ethics that says "one is a Negro to the degree to which one is wicked, sloppy, malicious, instinctual. Everything that is the opposite of these Negro modes of behavior is white" ( $B S$, p. 192). Hence Negrophobia becomes normal for the native black, who "lives an ambiguity that is extraordinarily neurotic" (BS, p. 192).

Such neurosis was encouraged in Fanon's birthplace, the French West Indian colony of Martinique. Until the Second World War, the middle class there considered itself (white) European rather than (black) African, and it erected its self-identity upon this "fundamental difference." ${ }^{34}$ But eventually Martinicans made the painful discovery that their whiteness was merely a mask. Fanon's was torn from him on his first extended visit to France when the whites he encountered in Paris fixed him in blackness. In recoiling from France, Fanon briefly turned to the flourishing Negritude movement led by his former teacher Césaire. But Fanon neither lost himself in Negritude nor returned home to his people. Instead, he embraced the cause of a country he had never set foot in - the white North African French colony of Algeria, a population composed largely of Muslims whose religion the Christian Fanon did not share and whose main language (Arabic) Fanon did not speak. He required a translator for his many Muslim psychiatric patients who spoke no French..$^{35}$ Routinely he would speak of "we Algerians," just as later he would speak of "we Africans." By then his political engagement went beyond Algeria

33. Du Bois, "The Conservation of Races," p. 825.

34. Fanon, Toward the African Revolution, trans. Haakon Chevalier (New York, 1967), p. 20; hereafter abbreviated TAR.

35. As commentators have noted, this situation of a European authority administering to natives reintroduced a colonial structure. See, for instance, Diana Fuss, "Interior Colonies: Frantz Fanon and the Politics of Identification," Diacritics 24 (Summer/Fall 1994): 2042, esp. pp. 36-38. 
to embrace all of Africa and, near the end of his life, oppressed peoples everywhere. When he died in 1961 he was buried in Algeria, and his fellow revolutionaries saluted him in Arabic: "the late brother Frantz Fanon finds himself, today, in the midst of his brother martyrs." ${ }^{36}$

Ten years after his death the official Algerian reaction sought to minimize Fanon's role, to "'de-Fanonize Algeria, and to de-Algerianize Fanon," in the words of one official. In short, "although he helped with 'our cause,' 'he was not one of us"' ( $F F$, p. 244). This attitude, notes Irene Gendzier, betrays a desire to "lay aside the ghost of a too-powerful Fanon" and to "protect the authenticity of the Revolution as an all-Algerian phenomenon" ( $F F$, pp. 244, 243). Authenticity is precisely what Fanon endangers, for he destabilizes the identity logic of us/them, identity/difference, inside/outside, native/stranger. Because it eludes these binaries, Fanon's life seems incoherent, an "impossible life" of no return and harrowing self-estrangement to those, like Memmi, who judge by the Cartesian terms of existential humanism.

These terms are blind to how Fanon's allegedly impossible life enabled him to introduce "invention into existence" and challenge the disciplinary logic of identity thinking (BS, p. 229). We have seen that Fanon reverses the trajectory of authenticity to instigate a crisis of origins. Analogously, he turns identity from the ground of being into an effect of practice: what we do determines who we are. The West Indian is buried an Algerian "brother." Fanon describes his leap of invention as Nietzschean in its effort "to educate man to be actional" rather than reactional (BS, $\mathrm{p}$. 222), and it approximates Nietzsche's dissolution of the subject into action: "The deed is everything"- "'the doer' is merely a fiction added to the deed." ${ }^{37}$ Making the deed everything, in Nietzsche and Fanon, demands that the past be evacuated, for history's humiliations viscerally weigh upon one in the present. The Negro "is the slave of the past," says Fanon, and "like it or not, the past can in no way guide me in the present moment" (BS, p. 225).

The extremity of Fanon's Nietzschean solution responds to the extremity of alienation endured by a black colonial subject. Du Bois's alienation under Jim Crow is just as palpable - as "a colored man in a white world" he felt "kept within bounds," neither an American nor a man ( $D D$, p. 653). But for Du Bois it would be unthinkable to jettison the past, since to work in the kingdom of culture is the very "end" of "striving." Yet Du Bois's historical embeddedness does not paralyze his will to invent. After all, he was trained by James in pragmatism, a kind of American version of the Nietzschean philosophy of action that Charles Sanders Peirce initi-

36. Quoted in Irene L. Gendzier, Frantz Fanon: A Critical Study (New York, 1973), p. 237; hereafter abbreviated $F F$.

37. Friedrich Nietzsche, On the Genealogy of Morals, trans. and ed. Walter Kaufmann (New York, 1969), p. 45. 
ated in his 1868 deconstruction of the a priori Cartesian subject. In this light we can place Du Bois's controversial claim that it was only at Fisk that "a new loyalty and allegiance replaced my Americanism: henceforward I was a Negro" $\left(A\right.$, p. 108) ${ }^{38}$ He replaces biology with will, thus turning a statement of identity ("I was a Negro") into a declaration of practice. At Fisk, recalls Du Bois, "I became a member of a closed racial group with rites and loyalties.... I received these eagerly and expanded them" $(D D$, p. 627).

Du Bois's statement anticipates the "end of the innocent notion of an essential black subject," a phrase of Stuart Hall's that points to the working premise of a number of contemporary thinkers. ${ }^{39}$ But even though opposition to a rhetoric of authenticity flourishes, this viewpoint, it seems fair to say, depends on its object of critique; that is, authenticity remains the given, the framework, in which debates and dissents are enacted. A vivid instance of the orthodoxy of authenticity is the celebrated Harvard sociologist Sara Lawrence-Lightfoot's 1994 book, I've Known Rivers. It is composed of lengthy interviews with six black professionals-"AfricanAmericans of privilege"-among them a professor, a scientist, an artist, an executive. The thread binding these self-narrations is a shared recognition of the "power of ancestry," a power that has inspired most of the speakers to make time in their busy lives for the journey home. The imperative of "reconnections with family origins" is at once the leitmotif of Lawrence-Lightfoot's book and the sine qua non of growth and creativity for her respondents, who otherwise, they claim, would feel emotionally desolate with their professional success. In her summation, LawrenceLightfoot declares, "I would say that each of these storytellers has grown 'blacker' as they have matured, stronger and less ambivalent in their identity as African-Americans." ${ }^{40}$ Ironically, a hundred years ago, such ada-

38. Lewis discusses Du Bois's "choice" in his W. E. B. Du Bois, p. 72.

39. Stuart Hall, "What Is This 'Black' in Black Popular Culture?" in Black Popular Culture, ed. Gina Dent (Seattle, 1992), p. 32. A number of people, including Isaac Julien, Samuel Delany, Michele Wallace, Paul Gilroy, and Kobena Mercer, are engaged in this project that Hall enunciates.

40. Sara Lawrence-Lightfoot, I've Known Rivers: Lives of Loss and Liberation (Reading, Mass., 1994), pp. 9, 10, 604. Lawrence-Lightfoot conceives of her book as a rejoinder to Franklin Frazier's famous 1957 study, Black Bourgeoisie, which portrayed the black middle class as deracinated, living "in a cultural vacuum," bereft of "cultural roots in either the Negro or the white world" (E. Franklin Frazier, Black Bourgeoisie: The Rise of a New Middle Class [New York, 1957], p. 112). There can be little doubt that the more nuanced portraits gathered in I've Known Rivers decisively overturn Frazier's indictment of the black bourgeoisie for the sin of allegedly disowning and hating their roots. Yet what is most significant about Lawrence-Lightfoot's rebuttal of Frazier is that it stays entirely within his terms. The centrality of roots, of return, of the "journey home" remains the unexamined premise, firmly in place as the measurement of authentic blackness. For another powerful statement, in the domain of literary criticism, of a commitment to the journey home as a measure of black psychic and moral health, see Houston A. Baker, Jr., Workings of the Spirit: The Poetics of Afro-American Women's Writing (Chicago, 1991). Baker seeks to honor narratives (by Hurs- 
mancy about identity, about return, loomed as a threat to those seeking to deracialize their relation to culture.

\section{Black Intellectuals and Other Oxymorons}

Controversy over African American identity is especially acute when one speaks of black intellectuals. They embody a double scandal. The first is the very fact of black literacy, a spectre that filled white Southerners with consuming fear throughout the nineteenth century. If caught reading, a slave's fingers or hands might be chopped off. "For coloured people to acquire learning in this country, makes tyrants quake and tremble," declared David Walker in his Appeal of 1829. ${ }^{41}$ He wrote with an accuracy that was also prophetic. Sixty years later, Washington's success rested in no small part on his ability to address and assuage this white horror of black literacy. Working hand in glove with Northern philanthropists, he made Tuskegee Institute into an instrument that would resolve what one of them, Robert Ogden, called "our great problem ... to attach the Negro to the soil and prevent his exodus from the country to the city." ${ }^{22}$ Such an exodus would spell economic catastrophe for Northern investments, as it meant the drying up of a steady supply of cheap, nonunionized, black farm labor to keep the cost of cotton profitable. Washington's path was clear: he was "careful not to educate" his students "out of sympathy with agricultural life" and risk having them abandon physical for mental labor - what he called living by one's wits. Washington supported college education only for those who would teach the black masses the supreme value of industrial training and a life of contented subordination. Tuskegee's goal was to provide "such an education as would fit a large proportion of them to be teachers, and at the same time cause them to return to the plantation districts." ${ }^{43}$

ton and Morrison among others) grounded on a "return to a southern place" of "black southern vernacular energies" where the "communal expressivity of black mothers and grandmothers" is given voice (pp. 30, 35, 36). To this solidarity he opposes black bourgeois women's texts (by Frances Harper, Anna Julia Cooper, and Pauline Hopkins, and their urban progeny Jessie Fauset and Nella Larsen) that exhibit varying degrees of dedication to currying "whitemale" approbation and erecting a "mulatto utopia," what Baker calls a "white-faced American noplace" (pp. 11, 30). An important alternative to Baker and Lawrence-Lightfoot is found in the contemporary feminist critique of the yearning for home, conducted by Teresa de Lauretis, Bernice Johnson Reagon, and others. The political theorist Bonnie Honig surveys this critique in her "Difference, Dilemmas, and the Politics of Home," Social Research 61 (Fall 1994): 563-97.

41. David Walker, Appeal (1829; New York, 1995), p. 31.

42. Quoted in James D. Anderson, The Education of Blacks in the South, 1860-1935 (Chapel Hill, N.C., 1987), p. 89.

43. Washington, Up from Slavery, in Three Negro Classics, ed. John Hope Franklin (1968; New York, 1980), pp. 96-97; hereafter abbreviated $U$. 
To insure this return, Tuskegee would keep book learning to a minimum, devoting itself to making the Negro humble and useful to the community. To that end students were discouraged from even being seen carrying books because, as Franklin Frazier personally remembered, "white people passed through the campus and would get the impression that Tuskegee Institute was training the Negro's intellect rather than his heart and hand." ${ }^{44}$ In Up from Slavery (1901) Washington recalled the early plans for Tuskegee and sympathized with white anxiety about starting a black college, remarking that those who had questioned the wisdom of creating Tuskegee "had in their minds pictures of what was called an educated Negro, with a high hat, imitation gold eye-glasses, a showy walking stick, kid gloves, fancy boots, and what not-in a word, a man who was determined to live by his wits" $(U$, p. 92). In merciful and stark contrast to this urban grotesque (borrowed from black dandy lore) stood serene Tuskegee, rooted, Washington implied, "upon the solid and never deceptive foundation of Mother Nature, where all nations and races that have ever succeeded have gotten their start" $(U$, p. 77$)$.

In enlisting "Mother Nature" as his staunch ally, Washington not only disguised the disciplinary technology of the Tuskegee machine but stigmatized any opposition. To be against Booker was to be against nature; hence black intellectual became a repugnant oxymoron, a corrupt and decadent monstrosity. A similar disgust, at approximately the same time, was being expressed on the other side of the world, but with different consequences. In Nigeria, the first generation of the Westerneducated elite were former slaves who returned from British missionary schools free and eager to uplift the unlettered majority. They had imagined themselves "the hope, ... the catalyst of a new Nigerian society" but before long discovered they were despised by the indigenous population as "moral and cultural lepers" and were refused recognition as "authentic members of society." 45 Such contempt took its toll and by the early 1880 s many members of the elite "began to perceive that they were rootless deluded hybrids" who had been educated "out of the Nigerian milieu" by British colonialism. In response, they "had to throw off the incubus of Western culture before they could be in a position to ... develop into authentic Nigerians" (EE, pp. 46-47). These are the words of a leading contemporary Nigerian historian-E. A. Ayandele-with a decidedly Bookerite take on Nigerian intellectuals. What Ayandele wants to emphasize is that the deluded hybrids successfully repented of their Western ways, discarded their English names and dress, swallowed a healthy dose of self-hatred (reproaching themselves as "'mongrels of humanity") and campaigned for the vernacular as the proper language of teaching. Some

44. Frazier, Black Bourgeoisie, p. 245 n. 15.

45. E. A. Ayandele, The Educated Elite in the Nigerian Society (Ibadan, 1974), p. 11; hereafter abbreviated $E E$. 
became devout preachers of the racialist "doctrine of African Personality" (EE, p. 47).

Fanon has described another, more general, instance of the abrupt oscillations of authenticity. By 1945, West Indians, humiliated by French racism, had come to realize the fraudulence of their European identity and had embraced Negritude. The Africa they had so long despised became the locus of "truth ... of an incorruptible purity" that West Indians now worshipped with all the passion they had once reserved for France (TAR, p. 25). In making black the "virtuous color," says Fanon, lightskinned West Indians were unwittingly "dancing on the edge of a precipice. For after all, if the color black is virtuous, I shall be all the more virtuous the blacker I am!" (TAR, p. 23). The "precipice" is the polarizing logic of authenticity that entrapped West Indians in guilt and despair, "haunted by impurity" (TAR, p. 26). As Fanon says in his famous concluding words to "West Indians and Africans," "it thus seems that the West Indian, after the great white error, is now living in the great black mirage" (TAR, p. 27). That "mirage" is a delirious fantasy of origin; imagining oneself a "transplanted son of slaves," feeling "the vibration of Africa in the very depth of his body," the West Indian "aspire[s] only to one thing: to plunge into the great "black hole" (TAR, p. 27).

Having experienced firsthand the futility inscribed in the pendulum swing of mirror-image opposites, Fanon vows to recover neither a white nor a black identity but, instead, to "reach out for the universal," the racially unmarked, by granting primacy to action rather than identity (BS, p. 197). What this reaching out makes possible is the intellectual. We will see that a number of black American intellectuals around 1900 share Fanon's logic if not his circumstances.

At the turn of the century, Du Bois, Charles Chesnutt, and Sutton Griggs faced the challenge of representing a figure who seemed neither to know his place nor to have a place and who seemed to affront every way of making sense of black identity in Jim Crow America. All three authors depict the black intellectual as synonymous with enigma: one character, humming Wagner, falls into a deathly trance (John Jones, in Du Bois's "Of the Coming of John"); another suddenly improvises a new identity and gender (Belton Piedmont, in Griggs's Imperium in Imperio [1899]); and a third proves unrepresentable altogether (John Warwick, né Walden, the mulatto protagonist of Chesnutt's The House Behind the Cedars [1900], who heads North to pass and abruptly passes right out of the novel, leaving his sister to enact the late nineteenth-century trope of tragic mulatta martyrdom).

No one was more aware of the affront embodied in the black intellectual than Du Bois, who distilled his awareness into the word problem at the opening of The Souls of Black Folk: "How does it feel to be a problem?" he asks, and adds that "being a problem is a strange experience," as if his identity and problem are synonymous. His identity is a problem not least 
because his goal is "to be a co-worker in the kingdom of culture," a phrase that deftly defines the vocation of the intellectual $(S, \mathrm{pp} .363,365)$. And this specific social role, in its uneasy, imposed distance from virtually everyone, including the illiterate black masses, governs his perspective in much of The Souls of Black Folk. Which is to say that this perspective is itself constituted by "two unreconciled strivings; two warring ideals"that of the intellectual and that of the race man $(S$, p. 364). This tension informs the narration of Du Bois's return to the rural South. Yet he returns not as a native but as a visitor, a summer teacher from Fisk, itself a far remove from his home state, Massachusetts, to which he will go back when he departs from Fisk for Harvard. Late in The Souls of Black Folk, $\mathrm{Du}$ Bois uses fiction to confront anxieties latent in "The Forethought"the precarious position of the black cultural worker ministering to his people. The painful question becomes, In what sense are they "his" at all? Indeed, "Of the Coming of John" narrates the shattering of this connection. The story explores how one's identity as an embodied "problem" - that is, a black intellectual-is yet further complicated once, in moments of aesthetic transport, one tastes "the free air" of life beyond the Veil of the color line' $(S$, p. 527).

After such knowledge, what forgiveness? What place does aesthetic bliss have in a black bourgeoisie devoted to racial uplift? It has none in the one socially sanctioned scenario of black intellectual activity-the "journey home," the return to rural Southern soil as one's base for Christian race work. In this arena, the exemplary tragic mulatta Iola Leroy (the titular heroine of Frances Harper's 1892 novel) will prosper as what we would now call, after Gramsci, an "organic" intellectual. Du Bois's acid comment on this approved ideal is discernible in the fate of his John Jones. After an intoxicating, if foreshortened, evening at the opera in New York City, he returns to his provincial roots to teach school in a world not unlike Iola Leroy's North Carolina plantation. Disaster quickly ensues; offending blacks and whites, John abruptly takes his suicidal leave. "I'm going-North," he tells his mother (S, p. 535). Those are his last words. And mentally he does go North. Lost in aesthetic reverie, John thinks of the "gilded ceiling of that vast concert hall" in New York and hears again "the faint sweet music" of Lohengrin $(S$, p. 535). He is in "dreamland," beyond the claims of white and black, as he sits with Wagner who winces not $(S$, p. 526). John is barely aware of the onrushing mob come to lynch him for killing the white man named John who molested his sister. The mob's leader had accused John Jones of wanting to "'reverse nature" by "'givin' talks on the French Revolution, equality, and such like"” ( $S$, pp. 531, 532). To reverse nature, one might add, also includes not making the journey home, not returning to Southern gardens and Southern mothers, not speaking black vernacular but, instead, severing roots and going North. Such reversals at worst risk death, at best flirt with being unintelligible. 
Belton Piedmont temporarily reverses nature in Griggs's novel when he leaves Virginia for New York, where he dons a woman's wig and a "well fitting" dress to pass as a nurse to a leading white family. His strategy may be postmodern but his mission is earnestly empirical - to discover from the inside what "precautionary steps the white people were going to take" in the event of a potential black "insurrection." 46 A self-styled "new Negro, self-respecting, fearless," Belton is part of a class of "educated malcontents" without professional prospects $(I, \mathrm{pp} .62,131)$. Alarmed at this frustrating impasse, which he fears may be breeding possible clandestine and anarchic violence, Belton has undertaken his mission. But all he learns is "that the white man was utterly ignorant of the nature of the Negro of to-day. ... He felt that the Negro was easily ruled and was not an object for serious thought" (I, p. 133). The white complacency Belton discovers may be insulting, but it provides the room Belton and other "new Negroes" need for forming the secret black shadow governmentthe Imperium - that is taking shape "unnoticed and . . . unseen" by indifferent whites $\left(I\right.$, p. 133). ${ }^{47}$ Although a nation within a nation, the Imperium, as Belton conceives it, is in an important way antiseparatist. For Belton regards the Imperium as the fruit of the universalist principles of liberty created in Western culture and also as a challenge that these principles in fact be extended to people of any color. Throughout, Griggs's fixation is skin color, but it operates less as a mark of race than of epidermal differences within the "whole human family" $(I$, p. 2). This universalism is one way to escape the "vicious circle" of self-revulsion described by Ayandele and Fanon.

Griggs and other "deluded hybrids" like Du Bois and Chesnutt emancipated themselves from the imprisoning rhetoric of authenticity, with its inevitable racializing of culture. Kelly Miller shows how this was done. In his 1905 "open letter to Thomas Dixon, Jr.," Miller, a Howard University professor of mathematics and later of sociology, rebuts the familiar claim that "the Negro lives in the light of the white man's civilization and reflects a part of that light."” The Negro, says Miller,

has advanced in exactly the same fashion that the white race has advanced, by taking advantage of all that has gone before.... The

46. Sutton Griggs, Imperium in Imperio: A Study of the Negro Race Problem (1899; New York, 1969), pp. 132, 131; hereafter abbreviated $I$.

47. Wilson Moses reads Belton's masquerade as Griggs's way of "hinting at the fact that some black men have allowed themselves to be emasculated by racism" (Wilson Jeremiah Moses, The Golden Age of Black Nationalism, 1850-1925 [New York, 1978], p. 186). Kevin K. Gaines concurs; see his Uplifting the Race: Black Leadership, Politics, and Culture in the Twentieth Century (Chapel Hill, N.C., 1996), p. 114. I read Belton's masquerade as exposing white blindness rather than black emasculation. Performing a mobile improvisation, Belton's cross-dressing is made possible by white complacency and both images and exploits his invisibility to whites. 
white man has no exclusive proprietorship of civilization. White man's civilization is as much a misnomer as the white man's multiplication table. It is the equal inheritance of anyone who can appropriate and apply it. ${ }^{48}$

Miller deracializes culture by making one's relation to it a matter of present action, not prior identity. What becomes pivotal is the capacity for practice, for appropriating and applying. ${ }^{49}$

If, for Washington, black intellectual is an oxymoron, Miller agrees, but for different reasons. For Miller, black intellectual is an oxymoron in the same way white intellectual is an oxymoron: to be an intellectual in the twentieth century (and in the wake of the Dreyfus affair) is already implicitly to offer a critique of the racializing of identity. Du Bois began discovering this during his aesthetic awakening in the art galleries of Europe as a graduate student in Berlin (1892-94). He was initiated not into the privilege of living in the light of the white man's civilization but into the practice of aesthetic contemplation, an initiation that in his Autobiography he depicts as concurrent with the "opportunity ... of looking at the world as a man and not simply from a narrow racial and provincial outlook" ( $A$, p. 159). "I sit with Shakespeare and he winces not" is Du Bois's most famous expression of how fused for him are aesthetic experience and the erasure of the color line ( $S$, p. 438).

Some regard Du Bois's and Miller's attitude to Western culture as smacking of genteel accommodationism or an assimilationism that whitens blacks. But such labels ignore the power of their position. For Du Bois and Miller, one's relation to culture and one's capacity for aesthetic experience are indifferent to the claims of an ideology of the authentic, with its fixation on origin, race, and ownership, the exclusionary mechanisms of an imperialist logic of identity. ${ }^{50}$ That logic, according to the antiracist, anti-imperialist James, carves up experience into static concepts and categories, tools that form the stereotypes on which a racially segregated social order depends. The concern of Jamesian pluralism is

48. Kelly Miller, "As to the Leopard's Spots," Radicals and Conservatives, and Other Essays on the Negro in America (New York, 1968), pp. 42, 55-56. This is a retitled reprint of Miller's 1908 Race Adjustment.

49. In Griggs's novel Belton Piedmont's views are congruent with those of Miller and Du Bois. By simply taking "possession of the great English language," the Negro "is thus made heir to all the richest thoughts of earth. . . . We can now enjoy the companionship of Shakespeare, Bacon, Milton, Bunyan, together with the favorite sons of other nations adopted into the English language, such as Dante, Hugo, Goethe" (I, p. 232).

50. While leaving James unmentioned, Said also links imperialism with identity thinking. He notes the "fundamentally static notion of identity that has been the core of cultural thought during the era of imperialism." This notion is founded on an unvarying idea: "that there is an 'us' and a 'them,' each quite settled, clear, unassailably self-evident" (Said, Culture and Imperialism, p. xxv). Said discusses the "epistemology of imperialism" in his "The Politics of Knowledge," Raritan 11 (Summer 1991): 21. 
not merely tolerance of multiplicity but, more precisely, the recovery of what James calls the "'unclassified residuum," that which slips the concept's grasp and encourages the "re-instatement of the vague," to borrow a phrase from The Principles of Psychology. ${ }^{51}$ In The Souls of Black Folk Du Bois carries on this reinstatement of the vague as a political and aesthetic project.

In a seldom-examined assessment of The Souls of Black Folk he published in 1904, Du Bois speaks of the "penumbra of vagueness and halfveiled allusion" that he has created around "a clear central message." While he notes that this vagueness has made some readers "impatient," it is "the nature of the message" that is at least partly responsible. ${ }^{52}$ That message is summarized in "The Forethought" to The Souls of Black Folk: "Herein lie buried many things which if read with patience may show the strange meaning of being black.... I have sought here to sketch, in vague, uncertain outline, the spiritual world in which ten thousand thousand Americans live and strive" ( $S$, p. 359). To excavate meanings long repressed under the weight of racist stereotype, Du Bois must step "within the Veil" of segregation and raise it so that the reader "may view faintly its deeper recesses" ( $S$, p. 359). Hence his immanent stance requires that vagueness be a condition of perception. Du Bois also assimilates the Veil of vagueness into a serpentine prose style that dissolves the stark rigidities bred by Jim Crow. In its elaborate delicacy and deliberate fusions and confusions of pronoun references, his style blurs divisions and grants respect for the intricacy of black experience. It demands the reader's openness to complexity. Vagueness becomes a tactic (admittedly risky) to frustrate stock responses by arousing the reader's sympathetic patience. The patience Du Bois urges was another practice he acquired in his aesthetic initiation in Europe: "I had been before, above all, in a hurry. I wanted a world, hard, smooth and swift" (DD, p. 587).

By embroidering his first nonacademic book with the aesthetic textures he had imbibed firsthand, Du Bois signals his intention to make The Souls of Black Folk a modernist artifact and not a collection of magazine articles. Difficulty and indirection become his chosen modes, the only ones flexible enough to do justice to the "strange experience" of "being a problem." To speak from within this experience is to achieve a kind of authenticity inimical to the kind mandated by Tuskegee's rhetoric of transparency. The authenticity $\mathrm{Du}$ Bois will pursue is founded on intimacy and vagueness, the subjectivity that is the hallmark of the modern.

51. James, The Will to Believe, and Other Essays in Popular Philosophy, ed. Frederick H. Burkhardt, Fredson Bowers, and Ignas K. Skrupskelis (Cambridge, Mass., 1979), p. 222 and The Principles of Psychology, ed. Burkhardt, Bowers, and Skrupskelis, 2 vols. (Cambridge, Mass., 1981), 1:246.

52. Du Bois, review of The Souls of Black Folk, in The Independent, 17 Nov. 1904, p. 1152; rpt. in Book Reviews by W. E. B. Du Bois, ed. Herbert Aptheker (New York, 1977), p. 9; hereafter abbreviated "R." 
Du Bois is thoroughly aware that his experiment is modernist. In his 1904 statement he speaks of renouncing "the usual impersonal and judicial attitude of the traditional author" as a loss "in authority but [a] gain in vividness." He mentions the "intimate tone of self-revelation," the "distinctively subjective note that runs in each essay" (“R," p. 9). The epistemological decentering Du Bois describes aligns him with modernism as it exchanges what might be termed an imperial mode of authenticity for a liberated modernist one. Du Bois topples the Olympian assumption of authorial omniscience for the new authenticity of vulnerability. The impersonal clarity of the imperial mode is replaced by freely confessed ambivalences and uncertainties, what $\mathrm{Du}$ Bois called in 1904 "abrupt transitions of style, tone and viewpoint," all leading to a "distinct sense of incompleteness and sketchiness" ("R," p. 9). But Du Bois sought more than to represent modernist subjectivity. He ends his self-assessment saying, "in its larger aspects the style is tropical-African. This needs no apology. The blood of my fathers spoke through me and cast off the English restraint of my training and surroundings" (“R," p. 9). Du Bois's mention of "blood" bespeaks a rhetoric of racial authenticity, but it does not take control of his discourse. Rather, he turns modernist and African aesthetics into twin sources of iconoclastic energy that overflow and intermix. Together they produce a hybrid text that casts off the restraints of the color line.

The Nigerian Nobel laureate Wole Soyinka describes "authenticity" as "one of the most vulgar frontiers ever raised against the creative impulse." It is used as "one of the main parameters of proscription which African writers and artists still have to undergo even at the tail-end of the twentieth century!" ${ }^{53} \mathrm{He}$ further condemns African "apologists for regimes which, waving the opportunistic rag of 'authenticity' as a banner, suppress forms of literature, or other art forms that may present a reality outside the glossy brochure" of state-controlled imagery dedicated to celebrating "the purity of African creative genius" ("NF," p. 221). In a combination worthy of Du Bois, Soyinka is a member of the Nigerian Western-educated elite (he writes in English) who has managed to remain an unrepentant "deluded hybrid" while also a leading democratic activist against Nigeria's totalitarian regimes ${ }^{54}$ His contempt for the proscriptions of state-mandated authenticity, directly influenced by Fanon, is inseparable from his fondness for the perverse indirections of the aesthetic

53. Wole Soyinka, "New Frontiers for Old," Art, Dialogue, and Outrage: Essays on Literature and Culture (New York, 1993), p. 219; hereafter abbreviated "NF."

54. Soyinka has been criticized as, in effect, a deluded hybrid. Kenyan novelist Ngũgĩ wa Thiong'o denies that Soyinka is an African writer and instead groups him with a "hybrid tradition ... that can only be termed as Afro-European literature; that is, the literature written by Africans in European languages" (Ngũgi wa Thiong'o, Decolonising the Mind: The Politics of Language in African Literature [London, 1986], pp. 26-27). Ngũgi's solution is to write in his native Kenyan dialect and translate his work into English. 
as it faces the imperative to communicate. Granting that the "artist's primary frontier" is "communication," Soyinka asks, "why do we encounter loiterers at its frontiers ... fragmenting and recomposing, or operating 'through a glass, darkly'? ... delaying, suspending or augmenting direct apprehension through a barrier of communication strategies" (“NF," p. 217).

Ambivalence about the instrumentality of direct communication and a preference for loitering and deferral characterize Soyinka's sense of the creative process and help explain his admiration for the "Art for Art's Sake" of "the last fin de siècle," which produced, he says, an "unprecedented" "liberation of the human imagination" in Europe, resulting eventually in modernism's "celebrated encounter with African art" ("NF," p. 218). Du Bois came to maturity in that time of liberation in the aesthetic nineties. He loved art as an enemy of what is purported to be "natural": "Art is not natural and is not supposed to be natural. And just because it is not natural, it may be great Art." ${ }^{55}$ Home from Berlin, he lectured rural blacks about European art, passed pictures around, and urged them to spend time in museums, for he realized that to promulgate respect for aesthetic autonomy was a social and political responsibility, not an evasion. Du Bois's insistence on aesthetic education is one way he renovates the inherited role of race man, ventilating the inherent constrictions of a public role devoted to uplift. "Group imprisonment within a group" is how Du Bois will bluntly describe why the race leader "congeals" into "provincialism" (DD, p. 651). As a wedge against this, Du Bois (like Soyinka) constructs the aesthetic as deferral and opposes it to the disciplinary yoke of authenticity.

Something of this urge for release helps explain, I think, why the Du Bois, Griggs, and Chesnutt texts are strikingly equivocal about pulling "the veil from before the eyes of the Anglo-Saxon that he may see the New Negro standing before him" (I, p. 244). This is Belton Piedmont articulating a goal to which these authors are at once committed and ambivalent about. Their works do indeed inform white America that "he has a New Negro on his hands" (I, p. 245). But rather than set him center stage, and thereby risk being bound by the conventions and constraints of imperial authenticity, of fixed identity, they preserve the black intellectual as an oxymoronic figure of racial inauthenticity. An "'unclassified residuum"" leading an impossible life, he is subject to abrupt narrative disruptions or terminations. Equivocation is expressed in Du Bois's unveiling his "New Negro" John Jones while sending him silently to his rapid doom and in Griggs's informing us of the vast black Imperium hidden on the margins of white America while having his hero Belton executed because he insists that the Imperium go public and abandon its plans to overthrow the U.S. government. There is equivocation also as

55. Du Bois, “Our Music," Writings, p. 1239. 
Chesnutt has John Walden describe himself and his sister Rena as "new people" but disappear North before giving that newness much enactment. ${ }^{56}$ Left behind to hold together The House Behind the Cedars is Rena, cast as tragic mulatta in the appointed script of the old Negro. ${ }^{57}$ In all three texts, ambivalence about representing the new Negro produces enigma and secrecy both thematically and as a narrative mode of maintaining power in reserve, a way of both representing and deferring representation. Thus illegibility becomes a source of potent possibility in Jim Crow's identitarian regime.

Chesnutt's figuration of the illegible is profoundly and creatively equivocal about representing the black intellectual. And in his last published story, "Baxter's Procrustes" (1904), Chesnutt offers a haunting allegory of this ambivalence. There the blankness that is John Walden's unrepresented Northern future becomes "'the wide meadow of margin"” that comprises Baxter's unwritten poem Procrustes. ${ }^{58}$ If The House Behind the Cedars is a book that does and does not represent a black intellectual (by depicting him as a man who decides to pass-both racially and from the novel), "Baxter's Procrustes" pivots on an analogous riddle: How does one publish a book without publishing a book? Chesnutt's protagonist, a melancholy, enigmatic aesthete, who over the years has occasionally read brief passages of a poem to friends, devises an answer; he publishes a "sealed" edition of his blank verse poem that, in reality, is nothing but blank pages-“all margin" ("BP," pp. 271, 277). A publication of the Bodleian Club, where genteel collectors are dedicated to the art of exquisite bookmaking, the poem is actually Baxter's practical joke on a world that this gloomy cynic finds "so uniformly monotonous as to be scarce worth the living" ("BP," p. 270). The joke mocks the pretensions of his smug fellow club members, who act as if they have "read" the poem (before it was sealed) and are fully confident that now they "'are so much the more intimately acquainted with Baxter-the real Baxter"” (“BP," p. 273). But Baxter, who is praised for having "'written himself into the poem," is as elusive as his Procrustes - that is, both are "all margin" ("BP, p. 273). No one knows what, if anything, is behind his mask of indifference. His joke

56. Charles Chesnutt, The House Behind the Cedars (New York, 1993), p. 57.

57. It is tempting to read The House Behind the Cedars as, on one level, Chesnutt's working-through of emotional ambivalences that grants him psychic permission to leave the South. His working-through involves a kind of psychic splitting; paying tribute (as tax and honor) to the past so as to be rid of it, he has Rena Walden perform the premodern, preordained sacrifice so that her brother can become an urban intellectual. But this formulation ignores that Warwick was first a Walden whose feeling at home with the past brings him back to Patesville in the first place. In other words, Chesnutt identifies not merely with John but with Rena. And, finally, with neither of them. Chesnutt was light enough to pass but chose not to. He neither stays (like Rena) nor passes (like John) but instead becomes a black intellectual, precisely in Miller's oxymoronic sense.

58. Chesnutt, "Baxter's Procrustes," Collected Stories of Charles W. Chesnutt, ed. William L. Andrews (New York, 1992), p. 274; hereafter abbreviated "BP." 
mocks both the presumption that we can know the "real Baxter" and the belief that we can confidently possess anything more than margin. Papering over this gap is the habit of certitude produced by the procrustean pressure of a society bent on uniformity, which catches "every man born into the world, and endeavor[s] to fit him to some preconceived standard" (“BP," p. 269).

Though the story's manifest content has nothing to do with race, Chesnutt's plea is for a margin as a defense against Jim Crow's procrustean one-drop demands of identity. In this light, Baxter's blank pages prove a pregnant image of anonymity, emptiness, and freedom to improvise. They are also a metaphor for the freedom of "pure Art" (Flaubert's phrase for his desire to write "a book about nothing"), for fin-de-siècle insouciance as a saving escape from the burdensome weight of imposed authenticity, of "preconceived standards." ${ }^{59}$ The blank pages evoke, as well, the blankness in The House Behind the Cedars created by John Walden's passing to the margins, to the space of his impossible life that escapes Southern doom for Northern possibility. ${ }^{60}$

Escape from the suffocating fatalism of the South preoccupied the young Chesnutt; a virtual obsession of his journal is the desire to go North and become a writer: "I pine for civilization, and 'equality"; "I will go to the Metropolis." ${ }^{61}$ Before moving North, he worked in North Carolina, pursuing a precociously brilliant career as an educator, all the while turning himself into an intellectual. Chesnutt rigorously educated himself in classical and European languages and literature; indeed few people have more tenaciously applied and appropriated the riches of "all that has gone before," to borrow Miller's words. Like Miller and Du Bois, Chesnutt understood intellectual as a nonracialized term ("it is the dream of my life-to be an author!"), and his "greatest desire," he tells his journal, is "to become a man in the highest sense of the word. I recognize the fact that my profession requires it of me" $(J C, \mathrm{pp} .154,167)$. As an intellectual in the rural South he felt "neither fish[,] flesh, nor fowl. ... Too

59. Gustave Flaubert, Selected Letters, trans. Francis Steesmuller (New York, 1954), pp. 127-28.

60. The black intellectual is invisible to those afflicted with procrustean vision, "'to those who see with one eye, speak with one tongue and see things as either black or white, either Eastern or Western." These words comprise the "dedication" and the only text of another blank book-“'My Life Story-by Mustafa Sa'eed"'-the work of the fictive African intellectual and aesthete of Tayeb Salih's novel Season of Migration to the North, trans. Denys Johnson-Davies (London, 1969), pp. 150-51. Once the toast of London and Bloomsbury in the 1920s, Said is an exotic hybrid nicknamed "'the black Englishman," who returns to live out his old age in his village near Khartoum and leaves behind his sparse autobiography (p. 53). In an uncanny echo of Chesnutt, Salih's empty pages also challenge readers to attain the requisite double vision-Du Bois would say "double-consciousness"- to see the black intellectual in the margins, occluded by preordained categories $(S$, p. 364).

61. Chesnutt, The Journals of Charles W. Chesnutt, ed. Richard Brodhead (Durham, N.C., 1993), pp. 172, 106; hereafter abbreviated JC. 
'stuck up' for the colored folks, and, of course, not recognized by the whites" (JC, pp. 157-58).

Rather than letting his sense of marginality paralyze him, Chesnutt turns this into a source of creative energy, as his earliest story, "Lost in a Swamp," reveals. It is a page-long story in his journal about a young man whose father tells him to ride five miles to get seed corn from a neighbor. He takes a "wrong turn" and gets lost in a swamp: "Instead of getting out of it, I was getting deeper and deeper into it." Eventually he extricates himself, gets his corn and, in the tale's last words, returns home, "to the great relief of my parent, who didn't know what was become of me." The journal's next line suggests what has become of him: "The above is my first real attempt at literature" $(J C$, p. 47$)$. What the tale stages is a creative birth wherein the act of writing is figured as immersion in a swamp, a losing of one's way, a wrong turn taken, a severance from roots. $\mathrm{He}$ returns to home and father the same but different-his father doesn't know "what was become" of him. Chesnutt will later describe his solitary life of unceasing intellectual labor as a continual "working in the dark. I have to feel my way along. ... I have become accustomed to the darkness" (JC, p. 92). His intellectual life thrives as subterranean, liminal, as if in the midst of his community he is adrift, present but not present. In daylight he is a teacher, at night a writer engulfed in a kind of swampnot of jungle oblivion but of consuming mental hunger, uncertainty, possibility, ambition. Chesnutt's fertile swamp of open margins is precisely the opposite of the terminal place that Rena stumbles into when "she ... realized with a horrible certainty that she was lost in the swamp." In panic she retreats deeper into the forest, to rejoin nature. She is found at "the edge of the swamp," next to a "well-defined path which would soon have led her to the open highway." ${ }^{2}$ Rena, dying, is returned to home, fixed in her procrustean fate, forever denied the open highway, the exit from nature, the margin of possibility. ${ }^{63}$

62. Chesnutt, The House Behind the Cedars, pp. 182, 183.

63. The bleak fate of black womanhood envisioned by Chesnutt is mitigated by $\mathrm{Du}$ Bois in his first novel, The Quest of the Silver Fleece (Chicago, 1911), where powerful agency is depicted as inseparable from two conditions: being a black female and being an intellectual. The novel narrates a return to roots without being a tragic mulatta tale. Instead, it is dominated by two black female intellectuals (Zora and Caroline), neither of whom is reduced to postures of noble self-sacrifice. Du Bois's novel functions as a bridge to modernity, reaching out to Nella Larsen's Quicksand (New York, 1928), which savagely mocks the plot of return, and to Jessie Fauset's anti-tragic mulatta urban romance Plum Bun (New York, 1929). By the fifties, the modernist cult of expatriation had made deracination the virtual sine qua non of the intellectual. In the preface to White Man, Listen! Richard Wright proudly proclaimed, "I'm a rootless man... I like and even cherish the state of abandonment" (Richard Wright, White Man, Listen! [Garden City, N.Y., 1964], p. xvi). In 1953, Fanon had written an admiring letter to Wright, stating that he was at work writing "a study bearing on the human breadth of your works" (Fanon, letter to Wright, 6 Jan. 1953, in Richard Wright: Impressions and Perspectives, ed. David Ray and Robert M. Farnsworth [Ann Arbor, Mich., 1973], p. 150). 
A century later the ubiquity of the black intellectual would seem to spell a new era of hypervisibility. But if this development-in a sense from oxymoron to tautology-does not also entail renouncing pursuit of an essential black subject, black intellectual life risks entrapment in polar oscillations of authenticity. In this light, the efforts by Du Bois and others at extrication around the turn of the century bear inspection. As does Fanon's impossible life. In reassessing these legacies, in turning Fanon and $\mathrm{Du}$ Bois, two prophets of sixties black nationalism, into prophets of nineties postethnicity, this essay has sought to take seriously what animates their projects-the leap, be it Nietzschean or pragmatist, from authenticity to invention. This leap revises the notion of legacy from serene repository to site of action. Otherwise one risks becoming "a prisoner of history" and exalting the past at the expense of the present and future (BS, p. 229). Fanon refused to be imprisoned, as did Du Bois: "No idea is perfect and forever valid," he told the NAACP in 1934 when its founding mission of integration was stalled. Although he had been present at its creation a quarter century before, Du Bois had no impulse to fetishize origins: "Always to be living and apposite and timely, [ideas] must be modified and adapted to changing facts" $(D D, \mathrm{p} .776)$. 